\title{
Pemikiran Jamaluddin al-Afghani dan Muhammad Abduh Serta Relasinya Dengan Realitas Sosial di Indonesia
}

\author{
Khairiyanto \\ UIN Sunan Kalijaga Yogyakarta \\ khairiyanto1992@gmail.com
}

Abstract: In the course of history, Muslims were as having experienced its heyday, where in many fields of science controlled by Muslims, it became the center of the world. This fact should be a motivation for Muslims to rise again from adversity as it is today. Sadly, Muslims regard this glory as nothing more than something to be proud of, furthermore Muslims feel that the text produced earlier is final and that there is no need to make a critical study of literature and the reality that surrounds their lives. However, this paradigm does not apply to Al-Afgani and Abduh, the article of these two figures aggressively voiced the importance of reason-rational in the study of religion and the importance of emulating the behavior of its predecessors, both aware that the revival era was important for Muslims. In this article we will discuss how religious thought is based on the modernity of al-Afghani and Abduh. This study uses a descriptive analysis method. According to al-Afgani and Abduh, in the socio-political field there needs to be unity, openness and cooperation that are built in order to obtain noble values and become part of progress.

Keyword: Thought, Theology, Social, Politic.

Abstrak: Dalam lintasan sejarah, umat muslim pernah mengalami masa kejayaannya, dimana dalam banyak bidang ilmu pengetahuan dikuasai oleh kaum muslim, hingga menjadi kiblat dunia. Kenyataan tersebut seharusnya menjadi motivasi bagi umat muslim untuk bangkit dari keterpurukan seperti kondisi saat ini. Mirisnya umat muslim mengagap kejayaan 
tersebut tidak lebih hanya sebatas sesuatu yang dibanggabanggakan, lebih jauh lagi umat muslim merasa bahwa teks yang dihasilkan sudah final dan tidak perlu mengadakan usaha kajian kritis pada telaah pustaka dan realitas yang melingkupi kehidupan mereka. Akan tetapi paradigma tersebut tidak berlaku bagi Al- Afgani dan Abduh, pasalnya kedua tokoh ini gencar menyuarakan pentingnya nalarrasional dalam pengkajian agama dan pentingnya meneladani perilaku pendahulunya, keduanya sadar bahwa era kebangkitan penting dilakukan oleh umat muslim. Dalam artikel ini akan membahas bagaimana pemikiran agama dengan nalar modernitas perspektif al-Afghani dan Abduh? Penelitian ini menggunakan metode diskrptif analisis. Menurut al-Afgani dan Abduh, dalam bidang sosial-politik perlu adanya persatuan, keterbukaan dan kerjasama yang dibangun guna untuk mendapatkan nilai luhur dan menjadi bagian dari kemajuan.

Kata Kunci: Pemikiran, Teologi, Sosial, Politik.

\section{A. Pendahuluan}

Dalam panggung sejarah, umat muslim memang pernah menorehkan tinta emasnya dalam kanca peradaban dunia. Berbagai bidang Ilmu pengetahuan, seni, dan teknologi pernah menjadi kiblat dunia. Akan tetapi umat muslim kemudian merasa bangga dan terlena dengan kejayaan yang ditorehkan serta karya yang dihasilkan dimasa lalu tanpa adanya upaya untuk melakukan inovasi dalam pemikiran, sehingga menyebabkan tenggelamnya rasionalitas didalam tradisi umat muslim. Kenyataan ini ditandai dengan keterbelakangan umat muslim terhadap kemajuan yang ada di Barat, disamping juga konflik internal didalam umat muslim itu sendiri. Seperti perbedaan dan perdebatan antara ulama, fiqh, tasawuf dan filsuf menjadi alasan yang tidak bisa dinafikan. Dalam arti, kewenangan dalam menentukan sikap pada syariah condong pada kebenaran masingmasing madzhab dengan sikap keunggulannya. Aspek lainnya ialah konflik teologis yang tidak berkesudahan semenjak khulafaur rasydin, yakni Usman dan Ali. Konflik teologis ini membawa dampak yang signifikan bagi umat Islam hingga masa sekarang. Perpecahan diantara umat Islam menjadi problem tersendiri. Oleh karenanya, hal ini menyumbat persoalan kemajuan, karena satu sama lain saling menyalahkan dan membuat konflik tidak berkesudahan. 
Akibat dari konflik tersebut, banyak diantara kelompok saling mengklaim kebenaran yang pasti.

Tidak hanya kelompok teologis dan kelompok fiqh yang terbagi pada beberapa madzhab membuat Islam mundur, tetapi juga kebijakan-kebijakan yang dilakukan oleh pemimpin Islam banyak melenceng dari upaya-upaya yang diidealkan oleh pendahulu mereka. Dalam arti, kebijakan yang mereka lakukan sudah tidak sesuai dengan pesan-pesan keilahian dan seruan yang diumbulkan oleh Nabi Muhammad SAW dan sahabat-sahabatnya.

Tindakan-tindakan yang tidak berkesesuaian dengan alQur'an dan sunnah nabi, menimbulkan tindakan-tindakan diluar batas, sehingga dari sebagian yang lain memilih jalan apatis terhadap kehidupan dunia dengan memilih jalan sufistik, hal ini berdasarkan kekecewaan pada mereka yang berkuasa. Kenyataan demikian itu membuktikan bahwa kemunduran Islam tidak hanya terjadi pada satu poros saja, meskipun kasus yang terjadi tidak keseluruhan di negaranegara Islam. Setidaknya hal ini membuktikan bahwa pemegang kuasa waktu itu belum sepenuhnya mampu menangkap pesan dan makna kesejatian spirit al-Qur'an dan Sunnah.

Ketika sains mampu melacak segala hal (konteks rasional dan empiris) dengan membaca entitas semesta sebagai ruang sains, dan membuat Barat berlomba-lomba menciptakan inovasi dalam hal pemikiran, sains, dan penemuan-penemuan ilmiah. Sementara di dunia Islam sendiri, masih sibuk dengan ritus kesucian agama, pertentangan, perpecahan, sehingga tidak pernah menyangka bahwa Barat mulai bangkit dan berusaha belajar dengan tekun pada hasil karya yang ditorehkan oleh umat muslim itu sendiri. Sementara umat Islam sendiri kurang begitu tertarik untuk mengkaji sains, yang sudah dianggap final dan hal tersebut berada pada kitab mereka yang tidak bisa dikaji secara ilmiah. Dikatakan demikian, kitab suci yang dipegang oleh umat Islam tidak untuk dikaji secara ilmiah, karena bisa mengakibatkan berkurangnya nilai spirit yang dikandungnya.

Baru setelah Barat melakukan ekspansi terhadap dunia Islam, umat Islam tersadar bahwa kemajuan yang dilakukan Barat luar biasa. Menariknya, jika para pendahulu mereka mampu menaklukkan negara-negara dengan berbagai ekspansi, maka sudah saatnya mereka dijajah dan kemudian menjadi budak dari Barat yang maju. 
Melihat kejadian ini, di abad 19 muncul beberapa pemikir muslim yang turut prihatin terhadap keadaan ini, diantaranya Jamal al-Din al-Afghani dan Muhammad Abduh. Keduanya adalah murid dan guru, dan proyeksi keduanya memiliki kesamaan dalam cara pandang. meskipun keduanya juga memiliki perbedaan yang signifikan, utamanya dalam hal sosial-politik.

Pemikiran Jamal al-Din al-Afghani dan Muhammad Abduh tentu sudah banyak yang meneliti, antara lain: Maryam, berjudul "Pemikiran Politik Jamaluddin Al-Afghani: Respon Terhadap Masa Modern dan Kejumudan Dunia Islam," Nurlaelah Abbas, berjudul "Muhammad Abduh: Konsep Rasionalisme dalam Islam,"2 Syaifuddin Qudsi, berjudul "Pemikiran Pendidikan Muhammad Abduh dan Proses Modernisasi Pesantren di Indonesia". ${ }^{3}$

Artikel membaca dan merefleksikan realitas dalam konteks keindonesiaan masa kini. Baik yang terkait dengan nalar pemikiran, sosial-politik, dan nalar teologis. Upaya pembacaan pada konteks keindonesiaan, ialah upaya menelaah konsep kedua tokoh tersebut dan menjadikan bahan pemikirannya sebagai titik temu pembaharuannya dengan nalar ketertutupan sebagian kelompok. Meskipun amat jauh kiranya dari sempurna, tetapi upaya ini tidak menutup kemungkinan sebagai bahan diskusi yang layak diperbincangkan. Sebagai suatu hasil refleksi, kedua tokoh tersebut sangat penting didiskusikan pada saat ini karena kecamuk sosialpolitik dan nalar teologis sebagian kelompok masih terbelenggu oleh momen masa lalu. Agar ketertutupan pemikiran tidak merambat lebih masif sehingga ruang dialektika keterbukaan semakin tidak terkendali.

Maka dalam tulisan ini, tokoh yang dikaji ialah Jamal al-Din al-Afghani dan Muhammad Abduh dalam konteks pemikiran politiksosial dan teologi. Penelitian ini menggunakan metode deskriptif

\footnotetext{
${ }^{1}$ Maryam, Pemikiran Politik Jamaluddin Al-Afghani: Respon Terhadap Masa Modern dan Kejumudan Dunia Islam, dalam Jurnal Politik Profetik Vol. 4, No. 2, 2014.

${ }^{2}$ Nurlaelah Abbas, Muhammad Abduh: Konsep Rasionalisme dalam Islam, dalam Jurnal Dakwah Tabligh, Vol. 15, No. 1, Juni 2014.

${ }^{3}$ Syaifuddin Qudsi, Pemikiran Pendidikan Muhammad Abduh dan Proses Modernisasi Pesantren di Indonesia, dalam jurnal Dirosat Journal of Islamic Studies, Vol. 1, No. 1, Januari-Juni 2016.
} 
analitis. Kedua tokoh tersebut mewakili kelompok reformatif dengan proyeksi menyinergikan masa lalu dengan masa kini.

\section{B. Pemikiran Jamaluddin al-Afghani}

Jamal al-Din al-Afghani merupakan salah satu tokoh atau figur salafi-sufi di abad modern. Meskipun ia salafi-sufi ia memiliki peranan yang penting dalam pembaruan pemikiran. Aktivitas dan pergerakannya dalam dunia pemikiran, sosial-politik menjadikannya dikenal di banyak kalangan. Tidak hanya itu, pemikirannya mampu menghipnotis beberapa pemikir setelahnya. Dengan itu pula, ia mampu melahirkan banyak pemikir yang berpengaruh di kalangan muslim. Salah satu muridnya yang kemudian memiliki pengaruh besar ialah Muhammad Abduh.

Pertemuannya dengan Abduh semakin memberikan banyak peluang untuk melakukan aktivitas politiknya agar terbebas dari kolonialisme yang dilakukan Inggris waktu itu. Dengan muridnya itu, ia kemudian mendirikan majalah yang diberi nama Al-Urwah alWutsqa. ${ }^{4}$ Majalah tersebut hanya terbit dalam 18 volume yang kemudian tidak diizinkan terbit lagi. Alasan majalah ini tidak diizinkan terbit disebarkan karena dapat membahayakan kepentingan kolonialisme dan imperialisme. Kelompok ini sudah mengindetifikasi bahayanya penyebaran majalah ini dan dapat menganggu perjalanan kolonialisme dan imperialisme. Sebabnya itu, pelarangan terbit dan penyebaran dapat meredam pengaruh al-Afghani di seluruh kalangan atau umat muslim di dunia.

Pengaruh kolonialisme Inggris telah mengubah banyak perilaku masyarakatnya. Sehingga ia tidak segan ingin mengembalikan spirit masa lalu dengan nuansa nilai pembacaan dengan term kemajuan. Dalam penilaiannya, ia melihat umat muslim sudah terlena dengan berbagai bentuk macam praktek agama yang sudah tidak sesuai dengan masa Nabi dan sahabat-sahabatnya. Hal ini pula yang mengganggu proses kemajuan dalam bidang keilmuan dan tertinggal pada Barat.

${ }^{4}$ Harun Nasution, Pembaharu dalam Islam, (Jakarta: Bulan Bintang, 1975), h. 53. 
Mengenai kelahiran al-Afghani sendiri ada dua versi, antara lain: versi pertama, Jamaluddin Al-Afghani dilahirkan di Afghanistan pada tahun 1839 dan meninggal dunia di Istambul pada tahun $1897 . .^{5}$ Versi kedua, Jamaluddin Al-Afghani lahir di kota Asadabad. Bagi orang Iran kebanyakan menyebut Jamaluddin dengan nama tambahan Al-Asadabadi, bukan Al-Afghani walaupun dunia telah terlanjur mengenalnya, sebagaimana juga yang dikehendaki yang bersangkutan yang bersangkutan sendiri dengan sebutan al-Afghani. ${ }^{6}$

Sejak muda ia sudah bergelut dengan berbagai bidang keilmuan, baik filsafat, teologi dan tasawuf. Dengan banyaknya pengetahuan yang ia miliki, ia sempat menjadi penasehat di Afghanistan. Hal demikian tidak berlangsung lama karena pendudukan orang-orang Inggris waktu itu menjadikan dirinya menghindari hal-hal yang kurang diinginkan. Demikian itu pula, kemudian ia melakukan perlawatan demi perlawatan dan keterlibatannya di dunia politik internasional.

Sebagai seorang pemikir Islam yang jelas al-Afghani tidak menginginkan suatu praktek yang tidak berkesesuaian dengan nilainilai keislaman. Dalam konteks ini, bukan berarti ia menolak hal-hal yang berdasar pada term Barat, melainkan bagaimana umat muslim bersatu untuk mengusir bangsa asing negara mereka. Praktik kolonialisme dan imperialisme merupakan cara yang kurang sesuai dengan nilai keislaman yang menjunjung asas-asas kemerdekaan sebagaimana yang dijalankan oleh Nabi Muhammad.

Jika umat muslim berada pada kamp-kamp kolonialisme dan imperialisme, sejatinya mereka sudah jauh dari nilai-nilai kemerdekaan. Baik dalam kemerdekaan individu, negara dan sumbersumber daya manusia yang lainnya. Jalan satu-satunya untuk terlepas dari mereka, al-Afghani menyerukan perlawanan kalau pun perlu dengan pertumpahan darah. Maka sejatinya dalam pandangannya, praktek yang tidak sesuai dengan nafas spirit keislaman yang menyanjung hak dan martabat kemerdekaan secara individu sudah saatnya dilawan.

${ }^{5}$ Muhammad Iqbal, Pemikiran Politik dari Masa Klasik Hingga Indonesia Kontemporer, (Jakarta: Kencana, 2010), h. 51.

${ }^{6}$ Nurchaklish Majid, Khazanah Intelektual Islam, (Jakarta: Bulan Bintang, 1984), h. 567. 
Dalam bidang teologi, ia mengekspresikan bentuk-bentuk awal yang pernah dilakukan oleh Nabi Muhammad dan sahabatnya. Pada prinsip ini, ia menawarkan tentang gagasan pemurnian Islam, aspek rasionalitas dan aspek yang berkenaan dengan fungsi kehidupan manusia di muka bumi. Dalam hal teologi, al-Afghani lebih kepada refleksi kehidupan manusia yang berdasarkan pada dimensi spiritual yang kuat dengan meninggalkan bentuk-bentuk yang acuh terhadap persoalan dunia dan akhirat.

\section{Politik-Sosial}

Pan-Islamisme dan marabahaya kolonialisme yang dilakukan oleh Barat menjadi hal terpenting dalam pemikiran sosial-politik alAfghani. Menurutnya, kemunduran Islam bukan karena ia tidak relevan dengan konteks zaman yang hadir saat ini. Namun, penyimpangan-penyimpangan yang dilakukan oleh penguasa Islam waktu itu yang tidak rela kedudukan mereka dilengserkan telah membuat umat Islam mundur sedemikian rupa dan membuat Barat semakin menguasai negara Islam. Penyimpangan yang dimaksud oleh al-Afghani ini semacam penyakit yang perlu disembuhkan dengan begitu serius.

Pan-Islamisme yang menawarkan gagasan pentingnya bersatu dalam persatuan dan kesatuan mampu membangkitkan semangat umat Islam di dunia. Negara seperti Afghanistan, Mesir, Turki, India, Al-Jazair dan negara-negara Islam lainnya. Suara-suara al-Afghani ini dilakukan dengan cara-cara mengisi ceramah diberbagai negara Islam dengan menyerukan pentingnya persatuan dan kesatuan umat Islam untuk melawan penjajah dan pemerintah yang sudah dikuasai oleh penjajah.

Adapun tawaran dari sosial-politik al-Afghani, sebagaimana yang disebutkan oleh Munawir Sjadzali (1991: 129), ialah pemikiran dan jiwa masyarakat harus terlebih dahulu dibangun dan dibenahi. Dengan demikian, baru kemudian berbicara mengena bentuk dan sistem pemerintahannya.

\section{Teologi}

Dalam hal teologi, al-Afghani menawarkan tiga pokok landasan yang perlu manusia lakukan pada kehidupannya. Pun tidak pula, pandangan konservatif yang sudah menjadi kadung dijadikan pegangan perlu dirombak dan ditata sedemikian rupa. Pandangan 
teologi al-Afghani lebih kepada usaha manusia mewujudkan dirinya menjadi manusia yang memiliki perilaku yang menekankan aspek spiritual. Dengan demikian, al-Afghani menolak cara pandang materialisme dan naturalistik yang cenderung dibangun oleh Barat.

Dalam pandangan teologi al-Afghani bukan berarti menolak Barat secara membabi buta, namun setidaknya ada penyaringan yang ketat dalam hal akidah. Penggunaan ketat di sini, bukan berarti ia anti Barat, melainkan umat Islam lebih mawas diri pada pribadinya sebagai makhluk yang memiliki Tuhan. Sehingga dengan begitu, umat Islam dapat bangkit dan berusaha semaksimal mungkin dengan melakukan telaah secara kritis pada apa yang menjadi produk Barat, pun meninggalkan taklid buta kepada para pendahulu yang dianggap sudah final dalam hal apapun.

Adapun ketiga hal pokok teologi yang ditawarkan oleh alAfghani ialah sebagai berikut: ${ }^{7}$

a. Sifat malaikat atau spiritual manusia yang merupakan tuan segala makhluk. Dalam arti kata, bahwa manusia merupakan makhluk yang secara spiritual memiliki aspek tertinggi daripada malaikat. Hal yang berkenaan dengan manusia dapat mencapainya dengan meniadakan unsur-unsur kehewanan yang merupakan tabiat terburuk manusia. Karena manusia yang memiliki jiwa spirit yang tinggi hanya akan sampai pada suatu kesadaran yang besar dan ingat bahwa upaya yang menjebak

b. Kepercayaan setiap umat beragama kepada keunggulannya sendiri atau segala kelompok lainnya. Hal yang ingin disampaikan oleh al-Afghani tidak lain hanyalah agar umat Islam sadar bahwa berlomba-lomba dalam mewujudkan kehidupan yang layak merupakan alasan tersendiri yang ditautkan oleh Islam. Dorongan yang terus memotivasi al-Afghani di sini tidak lain agar manusia berupaya melakukan telaah kritis baik pada pokok ajaran agama dan menjadikan al-Qur'an sebagai pusat kajian dengan terma rasional sehingga melahirkan corak tafsir baru, ijtihad ataupun dalam maju bidang pengetahuan.

${ }^{7}$ Majid Fakhry, Sejarah Filsafat Islam, terj. Mulyadi Kartanegara, (Jakarta: Dunia Pustaka Jaya, 1997), h. 455. 
c. Kesadardan bahwa kehidupan manusia di dunia ini hanyalah semata-mata suatu persiapan bagi kehidupan selanjutnya. Bahwa kehidupan yang sementara ini adalah kunci bagi manusia untuk mendapatkan kehidupan yang layak setelah kematian. Seyogyanya, manusia yang hidup dalam dunia terus berupaya mengikat tali persaudaraan dengan sesama muslim. Kontekstualisasi dari terma ini, mewujudkan kehidupan yang ideal dengan proses kasih sayang sehingga tidak menanggalkan wajah agama begitu saja. Pada sisi lain, kehidupan yang bersatu dengan satu kesatuan akan melahirkan sikap yang bijak dalam bertindak, berinovasi dan sebagainya. Sehingga kehidupan di dunia merupakan dasar yang pantas untuk menjadikan manusia melakukan suatu upaya demi kemajuan Islam di masa depan dengan berbagai temuan yang bermanfaat.

Pemikiran al-Afghani merupakan sintesa bagi keberlangsungan umat Islam di dunia. Pada konteks ini, kehidupan di masa lalu dapat disinergikan pada kehidupan saat ini sebagai telaah lebih mendalam bukan menerima begitu saja. Dalam artian, sikap seorang muslim perlu kritis pada masa lalu dan mencoba merefleksikan masa lalu dengan telaah yang lebih mendalam. Maka, status kemajuan dalam sosial-politik memiliki kesinambungan dengan nalar teologisnya dengan menekankan aspek kehidupan masyarakat sebagai suatu pembentukan terhadap individu.

\section{Pemikiran Muhammad Abduh}

Pemikir yang satu ini, memiliki kekhasan dan keunikan di antara pemikir lainnya. Hal yang membuat dirinya unik ialah rasa malas, namun memiliki kecerdasan yang luar biasa. Dalam waktu dua tahun ia mampu menghafal al-Qur'an. Dengan bekal kecerdasannya itu, ia kemudian dikirim ke salah satu lembaga pendidikan yang bernama Tanta. Selama itu pula, ia tidak menemukan hal-hal yang baru kecuali rasa bosan itu sendiri. Menghadapi hal demikian, ia kabur dan pergi ke rumah pamannya. Di tempat inilah, kemudian ia menemukan atmosfir baru di bawah bimbingan pamannya.

Terlepas dari berbagai sekelumit kisah Abduh itu sendiri, ada yang menarik darinya sebagai tokoh reformis dalam Islam. Meskipun ia salah satu murid dari al-Afghani dan banyak dipengaruhi olehnya. Namun ada yang berbeda dalam hasil pemikirannya tersebut. Jika al- 
Afghani menyerukan kebebasan umat Islam dari penjajah dalam bidang politik, maka Abduh lebih kepada realisasi dalam bidang pendidikan. $^{8}$ Dalam arti kata, Abduh terinspirasi dari peristiwaperistiwa di masa lalu yang melihat konsepsi pendidikan yang cenderung lebih kepada pengajaran konservatif dan monoton.

Dalam bidang teologi Abduh tidak jauh berbeda dengan alGhani, hanya saja ia lebih melihat kepada peranan rasio individu. Aspek mendasar ini sebenarnya tidak lain bahwa akal dapat memberikan suatu telaah yang lebih mendasar bagi kehidupan beragama seseorang utamanya pada pokok ajaran Islam. Dengan gencar ia menitikberatkan kepada peranan rasio, kebebasan dan bagaimana umat Islam terus berupaya memiliki kepercayaan yang sepenuhnya kepada Allah. Hal-hal yang berkenaan dengan dimensi spiritual, bahwa akal bisa mengantarkan manusia berperan pada sikap yang kritis terhadap kondisi di masa lalu.

Muhammad Abduh memiliki nama lengkap Muhammad bin Abduh bin Hasan Khairullah. ${ }^{9}$ Mengenai kesepakatan kelahiran Abduh yang menjadi catatan resmi oleh berbagai kelompok sejarawan dan dipakai oleh umum ialah tahun 1849. Ada juga yang menyatakan bahwa Abduh dilahirkan pada tahun 1848, namun tahun ini kurang begitu populer dikalangan sejarawan. Mengingat hal perbedaan pendapat mengenai kelahiran Abduh, tidak lain karena kejadian sosial-politik di waktu itu. Sehingga orang tua Abduh tidak sempat mencatat tanggal, bulan dan tahunnya dikarenakan kedua orang tuan berpindah-pindah tempat. Maka dengan mengacu kepada kesepatakan umum, peneliti memakai tahun yang sudah dipakai oleh kesepakatan banyak penelitian yang dilakukan sebelumnya. Ia dilahirkan dari keluarga petani pada tahun $1849 \mathrm{M}$ atau $1266 \mathrm{H}$, di suatu desa di Mesir Hilir, kemudian ia wafat pada tahun (1905 M/1323 H). Kecerdasan Abduh sudah terlihat sejak kecil ketika ia sudah tahu membaca dan menulis. Banyak pengalaman pahit yang dirasakan oleh Abduh dalam hal belajar di sekolah-sekolah.

${ }^{8}$ Nurlaelah Abbas, "Muhammad Abduh: Konsep Rasionalisme dalam Islam," dalam Jurnal Dakwah Tabligh, Vol. 15, No. 1, Juni 2014, h. 54.

${ }^{9}$ M. Quraish Shihab, Studi Kritis Tafsir Al-Manar (Bandung: Pustaka Hidayah, 1994), h. 11. 
Ketika Abduh bersekolah, ia merasa bahwa tidak ada sesuatu yang paling mengesankan. Sebagaimana yang dikisahkan oleh banyak sejarawan ataupun yang menulis tentang biografi Abduh, bahwa ia pernah sekolah di Tanta dan Al-Azhar. Ia menyebut bahwa sekolah tidak memberikan suatu dongkrakan yang begitu masif kepadanya. Dalam artian, pembelajaran di sekolah yang cenderung membosankan tersebut menjadi bukti bahwa umat Islam menjadi terbelakang. Dengan demikian itu pula, ia kemudian banyak menulis tentang pendidikan yang kemudian menjadi basisnya dan begitu dikenal di berbagai dunia.

Kejenuhan Abduh mulai terobati setelah bertemu dengan alAfghani yang memberikan banyak makna bagi perkembangan belajarnya dikemudian, dan mampu mencetuskan rumusan pendidikan yang memukau dibandingkan yang lainnya. Meskipun tidak dapat dipungkiri bahwa hal demikian sudah terlihat semenjak ia masif berdiskusi dengan pamannya.

Pertemuan Abduh dengan al-Afghani merupakan pesona tersendiri baginya. Banyak perubahan yang terjadi padanya, baik dalam bidang sosial-politik dan pendidikan. Dalam pada hal ini, konsep pemikiran pendidikan Abduh banyak menginspirasi berbagai kalangan. Pengajaran yang hanya berbekal pada budaya hafalan akan membuat siswa semakin bingung dengan tipe ini membuat kesulitan nalar rasio siswa. Sebabnya umat Islam akan berada pada garis belakang alias tidak memiliki kemajuan yang signifikan karena nalarnya tidak digunakan untuk menelaah kajian teks secara kritis.

Dalam bidang teologi, ia lebih memilih pada ketentuan bahwa manusia bebas menentukan perbuatannya, baik yang berhubungan dengan tindakannya hanya saja ada batasan-batasannya, juga persoalan takdir dan fungsi akal. Dengan demikian, fungsi akal menjadi peranan penting dalam tindakan manusia. Sehingga manusia dapat menentukan sikap dan pilihannya dalam hal apapun dan dapat menilainya dengan sebaik mungkin. Perangai ini memang lebih condong kepada penggunaan akal, hanya saja membatasi pada perangai bahwa ketentuan bahwa hukum alam menjadi alasan mendasar yang perlu manusia ketahui. 


\section{Sosial-Politik dan Pendidikan}

Dalam bidang sosial, sebagaimana gurunya al-Afghani memiliki proyek yang sama dalam menindaklanjuti bahwa hal yang sangat diperangi dalam hal ini ialah kolonialisme dan imperialisme yang dilakukan oleh Barat. Bahwa umat Islam menjadi terbelakang karena secara totalitas menolak produk dari Barat dan terlalu mengagungkan produk sendiri. Itu pun dengan dasar taklid buta dan seolah membiarkan taklid menjadi unsur yang paling nyaman dan paling dianggap relevan pada saat ini.

Sikap yang seharusnya dilakukan oleh umat Islam ialah bersikap kritis pada aspek keduanya, baik yang berasal dari kalangan sendiri dan kalangan Barat. Selayaknya yang perlu dilakukan oleh umat Islam ialah dengan bersikap kritis pada pola-pola Barat dan terbuka pada hal yang positif. Begitu juga sebaliknya, bahwa peranan kritis itu ada pada upaya menjauhkan diri dari persoalan taklid. Sebab bagaimana pun, karya ulama' belum sepenuhnya dianggap final dan perlu penyesuaian dengan nash al-Qur'an. Jika hal demikian dapat sesuai dengan nilai spirit al-Qur'an berarti hal demikian perlu dikerjakan, dan begitu juga sebaliknya.

Aktivitas politik Abduh sebagaimana pula gurunya, ia pernah dijebloskan ke dalam penjara karena terlibat dalam revolusi Urabi Pasya. Bersama pemimpin lainnya ia ditangkap, dipenjara dan kemudian dibuang keluar negeri pada tahun 1882. Pada tahun 1884, ia bersama-sama Jamaluddin al-Afghani mendirikan majalah "al'Urwah al-Wuthqa $\bar{a}$ " di Paris. ${ }^{10}$ Penangkapan Abduh juga memiliki alasan tersendiri, karena ia dianggap bahaya oleh penguasa waktu itu dan perangainya memang kurang banyak disukai oleh kalangan sendiri dan kelompok kolonial-imperialis.

Dalam hal pendidikan, ia banyak memberikan perhatian dibidang ini. Ketika ia berusaha memasukkan pengajaran filsafat di Al-Azhar sebagai tempat dirinya menimba ilmu. Hanya saja, usaha yang dilakukan oleh Abduh tidak membuat kebanyakan orang suka. Sebab, ia melakukan kritik terlalu pedas, bahwa unsur yang penting untuk dikaji adalah persoalan sains, sejarah pun hal yang berkenaan dengan prinsip keagamaan orang Eropa. Bahwa kewajiban belajar

${ }^{10}$ Ali Rahnema, Para Perintis Zaman Baru Islam, (Bandung: Mizan, 1996), h. 38 . 
tidak tertuju pada poros buku-buku klasik yang menjemukan. Maka dalam hal ini, Abduh banyak berupaya dalam reformasi pendidikan.

\section{Teologi}

Dalam konteks teologis, Abduh menawarkan tiga hal, antara lain:

1. Kebebasan manusia dalam bertindak, bahwa manusia memiliki peran yang signifikan bagi dirinya sendiri bahwa apa yang dilakukan sudah merupakan suatu bukti. Bahwa kebebasan manusia merupakan upaya eksistensinya di dunia yang dihadapkan pada situasi pilihan atas tindakanya. Hanya saja, kebebasan manusia ada batasannya, dalam hal ini ialah: pertama, manusia melakukan perbuatan dengan daya dan kemampuannya, kedua, kekuasaan Allah adalah tempat kembali semua yang terjadi. ${ }^{11}$

2. Kepercayaan kepada sunnah Allah dalam artian bahwa hukum alam sebagai realisasi dengan proses penciptaan sudah diatur oleh Allah yang tetap dan tidak berubah-ubah. Keniscayaan merupakan paling intim bahwa apapun yang diciptakan oleh Allah sesuai dengan sifat dan ketentuannya pada manusia dengan prinsip bahwa berpikir untuk dan memilih sesuai dengan tindakan manusia. Dengan menegaskan bahwa manusia disesuaikan dengan kadar kemampuannya baik dalam bertindak dan berpikir.

3. Fungsi akal memiliki peranan yang khas bagi manusia. Sebagaimana akal dapat memilah-memilih hal-hal yang dianggap baik dan buruk. Pada konsep ini, fungsi akal juga dapat mengetahui peranan wahyu, pun juga persoalan menyangkut hal lainnya. Bahwa fungsi akal dapat dilakukan dengan upaya yang selaras dengan apapun yang berkenaan dengan agama.

Dalam aspek ini, bahwa Abduh menginginkan individu mulai merefleksikan dirinya sebagai refresentasi dari kehidupan bernegara sehingga dalam fakta ini, untuk sebuah kemajuan karena ada ruang individu. Keyakinan ini bertolak belakang dengan gurunya yang menentukan proses kemajuan tidak pada negara.

${ }^{11}$ Mohammad, dkk, Tokoh-tokoh Islam yang Berpengaruh Abad 20, (Jakarta: Gema Insani, 2006), h. 228. 


\section{Relasi Pemikiran al-Afghani dan Abduh Dengan Realitas Sosial di Indonesia}

Baik al-Afgani maupun Abduh memiliki kritik yang sama ketika pemikiran mereka direalasikan pada konteks keindonesiaan. Menelisik sosio politik dan teologi di Indonesia sangat mengerikan dan sangat memperihatinkan. Akar permasalahan dan konflik yang tidak berkesudahan dengan ditambah dengan kemajuan tekhnologi yang satu sama lain saling serang dan saling mempengaruhi anggota kelompoknya untuk membenci pihak-pihak tertentu. Ragam masalah yang timbul disini sebagaimana berakar pada kepentingan individu dari suatu kelompok tertentu yang ingin diakui dan dianggap kuat.

Medan yang paling sehat untuk menjatuhkan orang lain dimedia sosial menjadi suatu alternatif dan jalan yang khas. Ujaran kebencian, sumpah-makian sudah menjadi trending topik yang memang menjadi suguhan setiap hari, baik kelompok elit politik yang ingin memperebutkan kekuasaannya untuk langgeng. Kelompok elit politik yang seolah berhak untuk mendapatkannya kekuasaan sehingga menjatuhkan adalah cara sehat yang penting dilakukan di media sosial. Keadaan tersebut diperparah oleh berbagai kasus korupsi dan rusaknya tatanan moral-etik yang sudah dianggap hal biasa dalam hal ini, proses kemajuan di Indonesia akan semakin sempit dan nalar ketertutupan semakin jelas menjadi jurang yang pasti tidak bisa terselamatkan. Alih-alih ragamnya kasus fisik yang terjadi dikalangan agamawan "mungkin" sudah tidak bisa diperbaiki. Banyak akademisi, ilmuan dan praktisi yang mencoba memberikan relasi guna mempertautkan nalar mereka yang sudah dianggap melenceng dari etika-rasio keagamaan. Dengan begitu, tidak salah kemudian ketika asing terus berupaya membuat negara ini semakin kacau dengan sistem kolonialisme-imperialis yang terus diupayakan.

Hilangnya kesadaran yang tinggi dari nalar rasio dan nalar intuitif menjadi beban tersendiri bagi kelompok pembaruan yang diwakili oleh akademisi dan kelompok-kelompok atau organisasi tertentu. Istilah ini semakin menjadi pokok atau bahan yang bisa membuat kolonial-imperialis mampu menancapkan kekuatannya di negara ini. Sebab bagaimanapun, sasaran empuk merek adalah 'konflik' yang dianggap cara ampuh menumbangkan negara ini. Tidak ada persatuan dan kesatuan lagi yang dalam konteks al-Afghani menjadi salah satu motif bangkitnya kemunduran Islam. Walaupun 
pada kenyataannya, di negara ini banyak agama yang diakui dengan berdasarkan pancasila.

Sistem pendidikan yang kaku, membuat parah negara ini semakin kalut. Jurang pemisah ini, banyak sekolah yang sudah melenceng dari poin-poin penting yang seharunya dijadikan nilai utamanya. Artinya, pendidikan hanyalah formalitas dari kehidupan rakyat Indonesia. Sistem yang digunakannya pun beragam, mulai menghafal, metode-metode yang dianggap pembaruan dikecam karena tidak sesuai dengan falsafah keislaman yang menitikberatkan pada akhlak. Namun, satu sisi nalar ini akan memperburuk kondisi kemajuan individual. Akibatnya, kondisi pendidikan semakin buruk dengan ditambah kondisi perekenomian yang mengerikan.

Pada konteks ini, Nahdatul Ulama dan Muhammadiyah dua organisasi yang memiliki peranan penting di Indonesia mencoba berupaya memberikan tawaran yang relatif memudahkan untuk proses kemajuan dalam bidang sosio-politik, pendidikan dan aspek lainnya. Namun kedua organisasi tersebut mendapatkan jurang yang tajam mengingat kelompok yang konservatif-fundamentalis yang bersikap acuh pada kemajuan. Serta menginginkan negara ini menjadi negara Islam. Hal yang tidak berkesesuaian dengan pemikiran mereka yang monoton tersebut menjadikan atmosfir yang membahayakan bagi keberlangsungan negara ini. Anehnya, ada elit politik yang memanfaatkan hal ini demi mencatut kekuasaan.

\section{Kritik pada Fundamentalisme}

Al-Ghani dan Abduh memiliki kritik yang tajam pada fundamentalisme yang cenderung abai pada kemajuan. Meskipun keduanya menyuarakan kembali kepada salafi di zaman Nabi dan sahabat, bukan berarti harus acuh pada kemajuan atau kegemilangan Barat. Pun tidak terlalu mengagungkan produk yang berasal dari Barat sedemikian rupa sehingga dapat mengganggu proses kemurnian dalam beragama. Kritik pada fundamentalis ini lebih kepada cara mereka yang cenderung apatis pada kekuasaan, dan bagaimana mereka membuat pola-pola yang sekiranya mendapatkan kemenangan dan menyingkirkan yang lainnya.

Kelompok fundamentalisme ini secara suara untuk mengembalikan nilai spirit pada era Nabi. Hanya saja, mereka tidak mencermati bahwa perilaku beliau selalu tampak sebagai rahmat bagi 
seluruh alam. Tindakan-tindakan mereka yang sama sekali tidak mencerminkan perilaku Nabi tersebut membuat kelompok ini menolak kelompok yang tidak sepaham dengannya. Kelompok ini lebih kepada teks-taklid secara membabi buta tanpa melihat teks yang lain pun berdasarkan konteks-sosio yang terjadi. Aspek ini sangat menghambat jalannya kemajuan baik dalam disiplin keilmuan dan sebagainya.

\section{Kritik pada Nalar Ketertutupan}

Kelompok fundamentalis, tentu saja tertutup dalam bidang keilmuan. Dalam arti, produk yang diusung Islam sudah final dan sangat anti-Barat. Hal ini mencerminkan bahwa fundamentalis tidak menerima teks yang sebenarnya memberikan dampak yang signifikan bagi kemajuan di Indonesia sehingga akan terasa ketika Indonesia semakin dijajah oleh bangsa asing. Meskipun secara kasat mata, kelompok asing menjajah secara mode, pemikiran dan aspek lain sebagainya. Dengan begitu, kekuatan asing akan semakin gencar dan menguat ketika kesadaran untuk mempelajari mereka semakin acuh dan dianggap tidak penting. Tidak adanya keterbukaan dan tidak adanya filter yang memadai akan sama-sama berbahaya. Pada yang pertama, bahwa keterbukaan dapat memberikan jalan untuk melihat, menganalisa bahwa pentingnya ilmu sains, serta yang berkenaan dengan hasil modernitas dan mensinergikan masa lalu dan masa kini. Tentu saja, mengacu pada prinsip-prinsip kemajuan dan perilaku para salafi terdahulu. Pada yang kedua, tidak adanya filter pun membahayakan karena tidak ada penyekatan bahwa meninggalkan perilaku salafi dapat mengakibatkan stagnasi di bidang akhlak dan agama. Dalam arti, keduanya harus saling bersinergi untuk mendapatkan kemenangan dan kemajuan.

\section{Kesimpulan}

Supaya umat muslim mengalami kemajuan terutama dalam bidang sosial-politik, maka perlu adanya kerjasama dan persatuan bagi umat muslim, untuk mendapatkan nilai luhur dan menjadi bagian dari kemajuan. Masyarakat secara umum dapat memberikan keluasan dan individu secara person bisa membangkitkan satu kesatuan yang pasti. Unsur keterbukaan begitu penting untuk mempelajari produk dari luar, baik itu dalam bidang teks, sains dan yang berkenaan 
dengan unsur modernitas. Disamping tentu tidak menafikan apa yang sudah dicontohkan oleh Nabi Muhammad dan sahabatnya. Hal yang mendasar terkait teologi ialah bahwa kepercayaan kepada Allah merupakan satu-satunya yang menjadi harapan terbesar bagi kehidupan manusia. Dengan begitu, manusia dapat menganalisa bahwa dirinya merupakan makhluk yang diciptakan oleh Allah, Sehingga, kehidupan pun selayaknya bersesuaian dengan kehendakNya dan akan selalu dapat sesuai dengan kondisi kemajuan zaman.

\section{Daftar Rujukan}

Abduh, Muhammad. 1992. Risalah al-Tauhid. Beirut-Lubnan: Dar Ihya al-'Ulum.

Abdullah, Amin. 2006. Islamic Studies Di Perguruan Tinggi: Pendekatan Integratif-Interkonektif. Yogyakarta: Pustaka Pelajar.

Bollouta, Issa J. 2002. Dekonstruksi Tradisi, Gelegar Pemikiran Arab-Islam. Pen. Imam Khoiri. Yogyakarta: LKiS.

Fakhry, Majid. 1997. Sejarah Filsafat Islam. Terj. Mulyadi Kartanegara. Jakarta: Dunia Pustaka Jaya.

Hj. Maryam, "Pemikiran Politik Jamaluddin Al-Afghani: Respon Terhadap Masa Modern dan Kejumudan Dunia Islam,” Jurnal Politik Profetik Vol. 4, No. 2, 2014

Iqbal, Muhammad. 2010. Pemikiran Politik dari Masa Klasik Hingga Indonesia Kontemporer. Jakarta: Kencana.

Majid, Nurchaklish. 1984. Khazanah Intelektual Islam. Jakarta: Bulan Bintang.

Mohammad, dkk. 2006. Tokoh-tokoh Islam yang Berpengaruh Abad 20. Jakarta: Gema Insani.

Nasution, Harun. 1975. Pembaharu dalam Islam. Jakarta: Bulan Bintang.

Nasution, Harun. 1987. Muhammad Abduh dan Teologi Rasional Mu'tazilah. Jakarta: Universitas Indonesia.

Nurlaelah Abbas, "Muhammad Abduh: Konsep Rasionalisme dalam Islam,” Jurnal Dakwah Tabligh, Vol. 15, No. 1, Juni 2014. 
Khairiyanto

Rahman, Fazlur. Islam. 1979. Chicago: The University of Chicago Press.

Rahnema, Ali. 1996. Para Perintis Zaman Baru Islam. Bandung: Mizan.

Shihab, M. Quraish. 1994. Studi Kritis Tafsir Al-Manar. Bandung: Pustaka, 1994), hal. 11.

Syaifuddin Qudsi, "Pemikiran Pendidikan Muhammad Abduh dan Proses Modernisasi Pesantren di Indonesia," Dirosat Journal of Islamic Studies, Vol. 1, No. 1, Januari-Juni 2016. 